\title{
Psikolojik Sözleșme Algısının Örgüte Bağlılığa Etkisi: Özel Eğitim Kurumlarında Görev Yapan Öğretmenlere Yönelik Bir Araştırma ${ }^{1}$
}

\author{
Ahmet YILDIRIM $^{1 *}$ \\ ${ }^{1}$ Asst. Prof. Dr, Süleyman Demirel University, Faculty of Economics and Administrative Sciences, Department \\ of Human Resources Management, Isparta, Turkey
}

Geliş Tarihi/Received: 12.09.2020

Kabul Tarihi/Accepted: 29.09.2020

Araştırma Makalesi/Research Article

\section{ÖZET}

$\mathrm{Bu}$ araştırma, psikolojik sözleşme algısının örgüte bağlılığa etkisini tespit etmek amacıyla yapılmıştır. Araştırmanın verileri, Isparta İl merkezinde eğitim-öğretime devam eden özel okullarda öğretmen olarak görev yapan eğitim çalışanlarından toplanmıştır. Bu kapsamda bahse konu olan okullarda görev yapan tüm öğretmenlere dijital ortamda ulaştırılan formlardan 134 anket formu değerlendirmeye alınmıştır.

Ulaşılan sonuçlara göre, Psikolojik sözleşme işlemsel psikolojik sözleşme boyutu ile örgüte bağlılığın duygusal bağlılık boyutu ve devam bağlılı̆̆ boyutu arasında pozitif ve anlamlı ilişki tespit edilmiştir. Bu bağlamda katılımcıların ilişkisel ve işlemsel psikolojik sözleşme algısı arttıkça duygusal ve devam bağlılı̆̆ına ilişkin algıları da artmaktadır.

Psikolojik sözleşmenin işlemsel ve ilişkisel sözleşme boyutlarının örgüte bağlılığın duygusal ve devam bağlılığı üzerinde olumlu ve anlamlı yordayıcısı olduğu, katılımcıların psikolojik sözleşmeye yönelik algıları arttıkça örgüte bağlılıkları artacağı ifade edilebilir. Bu bağlamda psikolojik sözleşmenin örgüte bağl1lık üzerinde pozitif ve anlamlı bir etkisi tespit edilmiştir. Ulaşılan bulgular literatür doğrultusunda tartışılmış ve gelecek çalışmalar için önerilerde bulunulmuştur.

Anahtar kelimeler: Psikolojik Sözleşme, Örgüte Bağlılık, Öğretmenler.

\footnotetext{
${ }^{1}$ Psikolojik Sözleşme Algısının Örgüte Bağlılığa Etkisi: Özel Eğitim Kurumlarında Görev Yapan EğitimÇalışanlarına Yönelik Bir Araştırma isimli çalışmamız Süleyman Demirel Üniversitesi Üniversite Etik Kurulu'nun17.07.2020 tarih ve 94/6 sayılı kararı ile uygun bulunmuştur.

* Sorumlu yazar/Corresponding author

E-mail/e-ileti: ahmet.yildirim@sdu.du.tr
} 


\title{
The Effect of Psychological Contract Perception on Organizational Commitment: A Research on Teachers Working in Private Education Institutions
}

\begin{abstract}
This research was carried out to determine the effect of psychological contract perception on organizational commitment. The data of the study were collected from education staff who worked as teachers in private schools continuing education in Isparta city center. In this context, 134 questionnaires from the forms that were delivered to all teachers working in the said schools in digital environment were evaluated.
\end{abstract}

According to the results, a positive and significant relationship was found between the operational psychological contract dimension of the psychological contract and the emotional commitment dimension of the organizational commitment and the continuation commitment dimension. In this context, as the relational and transactional psychological contract perception of the participants increases, their perception of emotional and continuance commitment also increases.

It can be stated that the operational and relational contract dimensions of the psychological contract are positive and significant predictors of the emotional and attendance commitment of the organization, and as the participants' perceptions of the psychological contract increase, their commitment to the organization will increase. In this context, a positive and significant effect of psychological contract on organizational commitment has been determined. The findings were discussed in line with the literature, and recommendations were made for future studies.

Keywords: Psychological Contract, Organizational Commitment, Teachers.

\section{GIRIŞ̧}

1980’lerden itibaren üzerinde ciddi tartışmalar yürütülen ve çeşitli düzeylerde araştırmalar yapılan bir kavram olarak değerlendirilen psikolojik sözleşme kavramının temelleri, odak noktası ve içeriği hakkında farklı yaklaşımlar söz konusudur.

Psikolojik sözleşme, örgütlerde çalışan ve işveren ile ilgili ortaya çıkan problemlere çözümler üreten çok yönlü bir yaklaşım olarak kabul edilmektedir. Psikolojik sözleşmenin çalışan ve işveren arasındaki önemli sorunlara çözüm sunan bir alternatif olması bu kavramı 
önemli kılmaktadır. Genel olarak karşılıklı yükümlülüklerin algılanması psikolojik sözleşme olarak nitelenebilir ve psikolojik sözleşme çalışan ve işveren algıları açısından incelenir (Saylı, 2003).

Psikolojik sözleşme çalışan ve örgütlerin ortak bir amaç için bir araya geldiği ve karşılıklı yükümlülükleri üzerine kurulu yazılı olmayan, konuşulmamış beklentilerin toplamıdır. Örgütler çalışanlarına iş garantisi ve adil bir ücret sunarken; bunun karşılığında çalışanlardan özverili çalışma ve sadakat beklemektedir. Örgüt ve çalışan arasındaki sözleşme, tarafların zımnen kabulüyle geçerlilik kazanan ve çalışma ilişkilerinin temelini oluşturan bir mahiyete sahiptir. Dolayısıyla “psikolojik sözleşme”, örgütler için önemli bir yönetim alanını doldurmaktadir.

Psikolojik sözleşmenin temel özelliği, taraflar arasında belirsizliği azaltması, çalışanlara, öngörebilme ve güven hissi vermesidir. Psikolojik sözleşmenin bir diğer önemli özelliği, çalışanın, kendisinin örgüte karşı olan yükümlülüklerini, örgütün kendisine karşı olan yükümlülükleriyle mukayese ederek tutum ve davranışlarını şekillendirmektedir. Örgütler açısından gittikçe karmaşık bir hal almaya bağlayan konjonktürel şartlar örgütsel bağlılık konusunun önemini arttırmıştır. Dolayısıyla örgütler çalışanlarından daha fazla özveride bulunmalarını, işlerine daha fazla motive olmalarını ve inisiyatif almalarını beklemektedir.

Kavrama dair olumsuz bir bakış açısını içeren "ihlal edilen psikolojik sözleşme" ise çalışan açısından verimsizlik, gizli işsizlik, saldırganlık gibi davranışlara yol açarken, işveren tarafında çalışana yönelik olumlu hislerinin değişmesine neden olmaktadır.

Örgüte bağlılık kavramına yönelik bir yaklaşıma göre örgütsel bağlılık "duygusal bir bağlılık" olarak tanımlanırken, çalışanların örgüte ait değerleri ve örgütün faaliyet amaçlarını benimsedikleri oranda bağlılık hissettikleri vurgulanmaktadır. Bir diğer yaklaşıma göre ise örgütsel bağlılık, çalışanların örgütlerine yaptıkları yatırımların sonucunda gelişen bir bağlılık olarak tanımlanmaya çalışılmıştır.

$\mathrm{Bu}$ araştırmanın amacı, özel okullarda görev yapan öğretmenlerin psikolojik sözleşme algı düzeyleri ile örgüte bağlılıklarını betimlemek, bu psikolojik sözleşme değişkeninin örgüte bağl1lık üzerindeki etkisini analiz etmek üzere gerçekleştirilmiştir.

Araştırmanın amacı çerçevesinde, öğretmenlerin işlemsel ve ilişkisel psikolojik sözleşme algılarının öğretmen-okul boyutunda örgüte bağlılık boyutları üzerine etkisi belirlenmeye çalışılmıştır. 


\section{PSİKOLOJİK SÖZLEŞME: KAVRAMSAL VE KURAMSAL TEMELLER}

1960'larda Argyris tarafından ilk kez kullanılan psikolojik sözleşme kavramı, alanyazında kendisine yer bulmaya başladığından itibaren farklı boyutları itibariyle değerlendirilmiş ve farklı anlamlar yüklenmiştir. Kavrama dair ilk değerlendirmelerin yapılmaya başladığı dönemlerden itibaren, Levinson, Price, Munden, Mandl, Sooley (1962), Schein (1965), Kotter (1973) ve Rousseau $(1989,1995)$ kavramı endüstriyel ilişkiler üzerine temellendirmeye ve bu kapsamda bir anlam bütünlüğü oluşturmaya çalışmışlardır (Zhoa vd., 2007). Bu bağlamda Kotter (1973: 91-99) psikolojik sözleşme kavramını, "kişi ve içinde bulunduğu örgüt arasında sözle ifade edilmeyen, kapalı, tarafların iş ilişkileri içerisinde birbirlerine vermeyi ve birbirlerinden almayı bekledikleri psikolojik yönü bulunan anlaşma" olarak tanımlamıştır.

1990’lara kadar psikolojik sözleşme kavramı çalışanın ve örgütün değişimini oluşturan karş11ıklı yükümlülükleri üzerine şekillenmiştir. Ancak, 1990'lardan sonra örgütler arası rekabetin boyut değiştirmesi, teknolojinin ortaya çıkardığg yeni fiili durumlar, tüketici tercihlerinde değişmeler, küresel nitelikli krizler gibi birçok nedene dayalı olarak örgütler kuvvetli bir değişim baskısı karşısında yeniden yapılanmak zorunda kalmışlardır. Bu yapısal değişime bağlı olarak örgütlerin psikolojik sözleşme kavramına ilgisi artarken, anlamı da performans odaklı hale gelmeye başlamıştır. Aslında bu durum, bir bakıma iş ilişkileri olgusunun psikolojik sözleşme kavramı ile anlaşılma gayretidir.

Psikolojik sözleşme kavramını "örgüt ve çalışan arasındaki ilişkide karşılıklı beklenti ve yükümlülüklerle ilgili olarak bireyin inanç ve algılamaları” olarak tanımlayan Rousseau (1990), kavramı etimolojik kökeninin dışında bir kabul, algı ve bilinç eksenine taşımıştır. Rousseau, "bireyin beklentileri neticesinde ortaya çıkan şartların bazılarının örgüt tarafından kabul edilmesi sonucunda psikolojik sözleşmenin oluştuğunu" ileri sürmektedir. Bu yaklaşım, psikolojik sözleşme kavramına olan ilgiyi arttırırken, anlam derinliği kazanmasına da imkân vermiştir. Schein (1980) psikolojik sözleşmeye dayalı anlamlandırmanın hem çalışanın hem de işverenin zihninde ayrı ayrı oluştuğunu düşünmektedir. Walker ve Hutton (2006: 434) psikolojik sözleşmeyi “örgütün ve çalışanın karşılıklı olarak yerine getirmeleri gereken yükümlülükleri içeren, ancak bireysel olarak çalışanın algılarına bağlı olan bir kavram” olarak tanımlayarak Roussea'ya yaklaşmışlardır.

Genel anlamda psikolojik sözleşmeyi çalışan ve örgüt arasında karşılıklılık temeline dayanan, dinamik, yazılı olmayan ve belirlenmiş beklentiler barındıran "sessiz anlaşma" olarak 
tanımlamak mümkündür. Dolayısıyla psikolojik sözleşme konuşulmayan sözler, tarafların iş sözleşmelerinde yazılı olarak ifade edilmemiş konuları içermektedir. Psikolojik sözleşmeyle işveren çalışanından; işine bağlılık, dürüstlük, özverili iş yapma, aşk ile işine sarılmasını beklerken, çalışan, önemsenmeyi, iyi iş ilişkilerinin oluşturulması ile ilgili psikolojik beklentiler içerisine girmektedir. Bahse konu olan beklentiler, çalışan ile örgüt arasındaki psikolojik sözleşmenin temellerini oluştururken verilen vaatlerin yerine getirilememesi, kişide hayal kırıklığı oluşturmakta ve çalışan açısından sözleşme bozulmaktadır (Rousseau, 1995).

Rousseau ve Schalk (2000), psikolojik sözleşmenin söz konusu olabilmesi için "bireyin kendisini özgür hissetmesi” ve “ çalışan ve işveren kararlılığı” olmak üzere iki ön şartın varlığından bahsetmektedirler. Dolayısıyla psikolojik sözleşme bir gönüllülük ilişkisidir ve bireylerin özgür iradesi ile anlam bulmaktadır (Kidder ve Buchholtz, 2002). Bu bağlamda Rousseau ve Schalk'ın (2000) öne sürdükleri ön şartı, temelde bir yeter-şart olarak da değerlendirebiliriz.

Psikolojik sözleşme sürecinde güven, verilmiş sözler ve bireylerin inançları önem kazanmaktadır. Bu bağlam, tüm örgütsel boyutları kapsamaktadır. Psikolojik sözleşmeler çalışanların kendi veçhelerinden çalışma ilişkilerini nasıl yorumladığını açıklarken, diğer yandan bu çerçevedeki çalışma ilişkilerinde özel koşulların varlığını kabul ederken farklı görüşlerin varlığını da düzenler.

Psikolojik sözleşmenin işlemsel (transactional) ve ilişkisel (relational), dengeli, geçişsel (geçişken) olmak üzere dört boyutundan bahsedilebilir (Rousseau, 1995; Stephanie vd., 2007: 40). İşlemsel psikolojik sözleşme, “devamlılık ikramiyesi, performansa dayalı ücretler gibi her iki taraf açısından para ile ifade edilen özel değişimlerle” ilgilidir. İşlemsel sözleşme boyutu, dönemsellik esasına dayalı, hukuki arkaplanı olan ve ekonomik boyutları içine alan piyasa sözleşmeleridir (Rousseau, 1990: 391). Rousseau'ya göre bireyler; işlemsel boyutta örgütlerin adalet mefhumuna çok hassas olduklarını, işverenlerinin adil, dürüst ve doğru davrandıklarını düşünmektedir.

İlişkisel psikolojik sözleşmeler ise, sosyal sermaye özellikli olarak bir ilişkinin kurulması ve sürdürülmesi ile ilgili parasal olmayan değişimlerdir. İlişkisel duygusal sözleşmeler daha çok uzun vadeli istihdam ilişkilerini içermesine rağmen karşılıklı veya müşterek yükümlülükleri kesin değildir. Sözleşmenin kabulü ve yürürlüğe girmesi, işveren ve çalışanların gönüllü olarak karşılıklı taahhütlerin ve beklentilerin uygun biçimde algılandığında ortaya çıkar (Stephanie vd., 2007: 40). Dengeli sözleşme ise, performans gereklerinin yerine 
getirilmesi esasına dayanmaktadır. Geçişsel (transitional) sözleşme boyutunda örgütün çevresel şartlarına bağlı olarak hızlı bir değişim söz konusudur (Rousseau, 1995).

Alanyazına göre, psikolojik sözleşmeye dayalı şartlar yerine getirilmediği/getirilemediği durumlarda psikolojik sözleşme ihlâli gerçekleşmektedir. Psikolojik sözleşme ihlâli, yazılı olmayan bir sözleşmenin ihlâli olsa da çalışanların tutum ve davranışları üzerine önemli etkide bulunmakta ve psikolojik sözleşmelerdeki değişme, çalışanların tutum ve davranışlarındaki değişmelere dair ipuçları taşımaktadır (Dikili ve Bayraktaroğlu, 2013).

Yönetim alanyazınında psikolojik sözleşme kavramına bakış açısı, daha çok "biçimsel (ilişkisel, işlemsel), içeriksel (algılanan yükümlülükler veya dönüşümün türü) ve ihlaller” düzeyinde ele alındığı görülmektedir (Millward ve Brewerton, 2000).

Psikolojik sözleşmenin ve boyutlarının incelenmesi çalışanın tutum ve performansının değerlendirilebilmesinde oldukça önemlidir. Bu nedenle etkinliği giderek artan psikolojik sözleşme kavramının tutumlar üzerindeki etkilerinin ortaya konması, çalışan ve işveren arasındaki ilişkilerin düzenlenmesinde önemlidir. Dolayısıyla psikolojik sözleşmenin örgüte bağlılık üzerindeki etkilerinin incelenmesi alanyazına katkı sağlayacağı düşünülmektedir.

\section{1. Örgüte Bağlılık}

Rekabetin küresel bir denklem haline geldiği, teknolojinin ve dijitalleşmenin iş dünyasında etkinliğini sürekli arttırdığı bir ortamda örgütlerin varlıklarını sürdürmeleri ve daha da güçlenerek geleceğe doğru sağlam adımlarla yürüyebilmelerinde çalışanlar açısından örgüte bağlılık kavramı oldukça önem kazanmıştır.

Yönetim alanayazınında örgüte bağl1lık; çalışanların örgüte sadakati ve örgüte özdeşlik için motive edici bir güç olarak ifade edilmiştir. Birey bağl1lık ile örgütün felsefesini benimsemekte, örgütün vizyon ve misyon hedefleri doğrultusunda bir yapılanma hedeflemektedir. Dolayısıyla bireyle örgüt arasındaki intisap kişiyi örgütüne bağlayan bir katılım ve örgütle özdeşleştiren bir unsur olarak da tanımlanır.

İnsan sermayesinin örgütlerde rekabet avantajı sağlayan bir çarpan haline gelmesiyle birlikte örgüte bağl1lık 1970'lerde çok yönlü bir şekilde incelenmeye başlanmıştır. Örgüte bağlılık konusunda ciddi katkılar sağlamış olan Meyer ve Allen (1991) “örgüte bağlılığın 
psikolojik bir boyuta sahip olduğunu ve örgüt üyelerinin örgütle ilişkisi ile şekillenen ve örgütün sürekli bir üyesi olma kararı almalarını sağlayan bir davranış" olarak tanımlamıştır.

Örgüte bağlılık, çalışanın psikolojik bir sözleşmeyle işe dâhil olmasıyla başlar. Örgütün yeni bir üyesi olarak hedefler, amaçlar ve işin gerektirdikleri konusunda bilgi edinmesiyle gelişir. Bu bağlamda örgüte bağlılık, çalışanın örgüt ile kimlik birliğine girerek oluşturduğu güç birliğidir (Northcraft ve Neale, 1990: 464). Farklı bir bakış açısıyla örgüte bağl1lık, “örgütün üyesi olarak kalmaya güçlü bir istek, örgüt adına yüksek düzeyli çaba gösterme isteği ve örgütün değerlerine ve hedeflerine inanılmas1, benimsenmesidir." (Mowday ve Steers, 1979: 224).

Örgüte bağl1lık kavramı alanyazında tutumsal (attitudinal) ya da davranışsal (behavioral) olmak üzere iki farklı bakış açısıyla değerlendirilme eğilimi söz konusudur. Bir tutum (attitude) olarak dikkate alınan örgüte bağl1lık, örgüte duygusal/ hissi bağl1lık olarak anlamlandırılır. Örgüte duygusal yönden bağlı olan çalışanların örgütle bütünleştiğgi, örgütsel aidiyet geliştirdikleri, örgütün üyesi olmaktan hoşnut oldukları kabul edilmektedir.

Tutuma dayalı bağlılık ise, çalışanın değerlerinin ve amaçlarının örgütün değerleri ve amaçları ile uygunluğunu rasyonel bir şekilde uyumu olarak tanımlanabilir (Meyer ve Allen, 1991). Davranışsal bakış açısıyla örgüte bağlılığı ele alan yaklaşıma göre örgüte bağlılık işgörenlerin bir örgütte kalıp kalmamaya ilişkin seçimleri ile ilişkilendirilmektedir.

Alanayazında örgüte bağlılığa ilişkin tutumsal ve davranışsal yaklaşımların benzerlikleri ile birlikte farklılıklara da işaret edilmiştir. Bu farklılıkların içerisinde en dikkati çeken çalışanın psikolojik algısının bağlılığın gelişmesine yol açan belirleyici koşullar ve bağlılık sonucu beklenen davranışla doğrudan ilişskilidir.

Bazı çalışmalarda örgüte bağlılığın çok boyutlu nitelik taşıması gerektiği ileri sürülmüştür. Çok boyutlu örgüte bağlılık yaklaşımları içinde en bilineni Allen ve Meyer'in sınıflandırmasıdır. Allen ve Meyer (1990) örgüte bağlılık kavramı için bütüncül bir yaklaşım önermişler ve örgüte bağlılığın üç boyutu olduğunu ileri sürerek bunları duygusal, devamlılık ve normatif bağlılık olarak sınıflandırmışlardır.

Allen ve Meyer (1990) örgüte bağlılık yaklaşımlarında tutumsal ve davranışsal yaklaşımlar ile tamamlayıcı ilişkilerini birlikte ele almışlardır. Diğer bir ifade ile Allen ve Meyer tamamlayıcı ilişkiler kapsamında çalışanın örgütle ilgili hisleriyle ve/veya inançlarıyla 
ilgili psikolojik bir durum olarak dikkate almışlardır. Allen ve Meyer'in ortaya koyduğu örgüte bağl1lık modelinde "duygusal", "devamlılık" ve "normatif" bağlılık olarak adlandırılan üç boyut bulunmaktadır. Duygusal bağlılık, "kişinin hissi olarak örgüte bağlanmasını, örgütle özdeşleşmesini ve kendi istek ve tercihleriyle örgütte kalmasını" ifade etmektedir. Devamlılık bağlılığı, "örgütten ayrllmayla ilgili algılanan maliyetlerle ilişkilendirilmiştir ve çalışanların örgütten ayrılmaları durumunda katlanacakları maliyetleri, olumsuzlukları ya da örgütte kalmanın getirilerini dikkate alarak kalma kararı" vermesidir. Normatif bağlılık, "örgütte kalmaya yönelik algılanan zorunluluğu ifade etmektedir. Çalışanların hissettikleri görev duygusu ve yükümlülük ile örgütte kalmaları ve zorunlu bir bağlllık geliştirmeleridir" (Allen ve Meyer, 1990; Allen ve Meyer 1991; Erdil ve Keskin, 2003).

Çalışanların örgüte olan bağlılıkları farklı şekillerde tezahür edilmektedir. Çalışanların örgüte bağglılığını örgütün amaç ve değerlerini benimsemeleri ve örgütün vizyonuna inanmaları, örgüt üyeliğini devam ettirmek için güçlü bir istek, örgüt kimliğine aidiyet ve örgütün amaç ve politikalarını içselleştirmeleridir. Dolayısıyla çalışanın amaçlarını benimsemediği bir örgüte bağl1lık göstermesi beklenemez. Çalışanların örgütle kendilerini ilişkilendirmeleri ve örgütün faaliyetlerini onaylama eğilimi, çalışanların örgüte bağlılık derecesini ortaya koyacaktır (Karcioğlu ve Türker, 2010).

\subsection{Psikolojik Sözleşme Örgüte Bağlılık İlişkisi}

Günümüz koşullarında örgütlerin hedeflerine ulaşabilmelerinin temel koşulu, çalışanların örgüte bağlılığın sağlanmasıdır. Örgütlerin bu ortamda başarılı ve güçlü kalabilmeleri, özverili, gayretli çalışanların varlığına bağlı olduğu için de onların örgüte bağlılığını sağlamak kritik önemdedir. Niteliği gereği algısal bir temele dayalı kavram olarak psikolojik sözleşme kavramı, çalışan ve örgütün bir araya geldiği ve birbirlerine karş1 yükümlülükleri üzerine kurulu, yazılı olmayan, konuşulmamış beklentilerin toplamı olarak kabul edilmektedir.

Duyuşsal bir temele dayalı olması ve sözsüz iletişim ilkelerini barındırması nedeniyle sessiz anlaşma hükmündeki psikolojik sözleşme, doğrudan ve dolaylı bir şekilde çalışanın örgütle bütünleşmesini, örgütün amaç ve değerlerini güçlü bir inançla kabullenmesini diğer bir ifade ile örgüte olan bağlılığını artırmaktadır.

Psikolojik sözleşme, çalışan ve örgüt arasında çatışma ya da gerilime mahal bırakmadan, karşılıklı güven duygusunu yaratan ve fikir birliği içinde olmalarını sağlayan bir 
sözleşme, örgüt içindeki davranış, başarı ve gelecekle ilgili çalışmaları konu alıp, tarafların aralarında sessiz olarak anlaştıklarını gösteren bir süreçtir.

Kwon (2001) psikolojik sözleşmeyi "ilişkisel” ve "işlevsel” sözleşmelerle iş göreni örgüte bağlayan ve çalışan psikolojisini esas alan bir yapıştırıcı olduğunu düşünmektedir (Kwon, 2001). Psikolojik sözleşmeye dair bir şüphesi olmayan çalışan, olumlu ilişkiler kurar ve örgütün yararına davranışlar sergiler. Dolayısıyla psikolojik sözleşmeyi olumlu yönde algılayan çalışan yüksek seviyede örgüte bağlılık göstereceği ifade edilebilir.

Psikolojik sözleşme ile çalışan ve örgüt arasında güven duygusu ihdas edilecek, çalışan açısından duygusal bir bağ oluşacak, çalışan performansı ve verimliliği artacak böylece çalışanın işinden duyduğu tatmin yükselecek dolayısıyla çalışanın örgüte bağlılığı sağlanacaktır. Çalışanların yöneticileri ile uyumlu çalışmalarını, örgüt içindeki rolleri ve sorumluluklarının bilincinde olmalarını sağlayan psikolojik sözleşme, örgüt ve çalışan arasında yarattığı güven duygusu ile birlikte örgütsel bağlılığın sağlanmasına katkıda bulunabilmektedir.

Çalışan psikolojik sözleşmeyle örgütün kendini desteklediğini ve örgüt için önemli olduğu yargılarını geliştirecek ve bu yargılar da çalışanın örgüte sadakat, güven ve duygusal bağlılığını artıracaktır.

Psikolojik sözleşme kavramı sosyal mübadele kuramı çerçevesinde ele alınmaktadır. Sosyal mübadele kuramı, "tarafların, ödüllendirilme beklentisi (saygı görme, onur, arkadaşlık, dikkate alınma vb.) içinde sosyal ilişkilere girdiği ve bu ilişkileri sürdürmesi” temeline dayanır (Gefen ve Ridings 2002). Bu kurama göre çalışanın niyeti, beklentileri ile örgütün beklentileri ile örgütün önerdiği ödülleri takas etmeyi içermektedir. Çalışan ve örgüt süreç içerisinde ilişkinin fayda-maliyet analizini yaparak değerlendirmelerini yeni duruma göre günceller.

Psikolojik sözleşme üzerine Saylı (2002), Oğul Selekler (2007), Demiral (2008), Mimaroğlu (2008), Türker (2010) ile Karcıoğlu ve Türker (2010), Cassar (2001), Lemire ve Rouillard (2005) ile Willems vd. (2006) çalışmalarına ulaşılabilmiştir. Psikolojik sermayenin iş tatmini (Dikili ve Bayraktaroğlu, 2013; Ünver, 2011), örgütsel sinizm (Çetinkaya, 2014), örgütsel güven (Özgen 2010; Yılmaz, 2012) olmak üzere farklı değişkenlerle ilişkisi ele alınmıştır.

Allen ve Meyer (1990) tarafından ortaya konulan örgüte bağlılık kavramının özellikle duygusal yönünün sıkça araştırma konusu olduğu görülmektedir. Araştırmalar, duygusal 


\section{Ylldırım, $A$.}

bağlılıkla iş performansı, örgütsel uyum, verimlilik ve kalite, örgütsel vatandaşlık davranışı ve iş tatmini arasında olumlu; iş gücü devri ve devamsızlık arasında ise olumsuz bir ilişki olduğunu göstermektedir (Mathieu ve Zajac, 1990; Becker, 1992; Meyer ve Allen, 1997).

Ceseroğlu (2010), yaptığı araştırmada psikolojik sözleşme ile örgütsel bağlılık arasında anlamlı bir ilişki tespit etmiştir. Keman (2012), Mahia ve Bastos (2015), Tsuı vd. (2013) çalışmalarında, psikolojik sözleşmenin örgütsel bağlılık üzerinde etkisi olduğu saptanmıştır. Çetin (2010), Özgen ve Özgen (2010) psikolojik sözleşme ve örgütsel bağlllık algı düzeyleri arasında pozitif yönde ve çok yüksek düzeyde, Demiral (2008) ise pozitif yönde bir ilişki tespit etmiştir. Karcıoğlu ve Türker'in araştırmasına göre psikolojik sözleşme uyum algı düzeyleri ve örgütsel bağl1lık alg1 düzeyleri arasında pozitif yönde güçlü bir ilişki olduğu görülmüştür. Behery vd. (2012) çalışmalarında psikolojik sözleşme ile örgütsel bağlılık düzeylerinde herhangi bir etkiden bahsedilemeyeceğini ifade etmiştir.

Psikolojik sözleşme ve psikolojik sözleşme ihlalinin örgütsel bağlılığın azalmasına yol açacağı öngörülebilir. Bu bağlamda psikolojik sözleşme ihlalinin örgütsel bağlılığın azalmasına neden olduğunu ileri süren tespitler vardır. (Robinson vd., 1994; Robinson ve Rousseau, 1994; Robinson ve Morrison, 1995; Robinson, 1996; Turnley ve Feldman, 1999).

Çalışanların bağl1lı̆̆ı örgütle bütünleşmelerinin, örgütsel amaç ve değerleri kabullenmelerinin ve örgüt yararına olağanüstü çaba sarf etmelerinin bir göstergesidir (Allen ve Meyer, 1990). Buradan hareketle psikolojik sözleşme ile örgütsel bağlılık arasında ilişki varsayımında, sosyal mübadele temelli psikolojik sözleşme algısının örgüte bağlılığın boyutları üzerinde pozitif yönde etkisi olduğu ileri sürülebilir. Bu nedenle aşağıdaki hipotezler geliştirilmiştir.

H1. Çalışanların ilişkisel psikolojik sözleşmelerinin örgüte bă̆lılı̆̆ın duygusal boyutu üzerinde pozitif etkisi vardır.

H2. Çalışanların ilişkisel psikolojik sözleşmelerinin örgüte bă̆lllı̆̆ın normatif boyutu üzerinde pozitif etkisi vardır.

H3. Çalışanların ilişkisel psikolojik sözleşmelerinin örgüte bă̆lılı̆̆ın devamlılık boyutu üzerinde pozitif etkisi vardır.

Psikolojik sözleşme türleri bağlamında psikolojik sözleşmenin işlemsel boyutuna ilişkin ücret gibi maddi yararlar yükümlülüklerin bozulmasının iş tatmininde azalmaya yol açacağına 
dikkat çekilmektedir (Anderson ve Schalk, 1998: 641). Buna mukabili maddi getirilere odaklanan işlemsel psikolojik sözleşmeyle örgüte bağlılık boyutları arasında pozitif ilişkili bir etkinin varlığında bahsedilebilir. Bu nedenle, aşağıdaki hipotezler geliştirilmiştir.

H4. Çalışanların işlemsel psikolojik sözleşmelerinin örgütsel bă̆lılı̆̆ın duygusal boyutu üzerinde olumlu pozitif bir etkisi vardır.

H5. Çalışanların işlemsel psikolojik sözleşmelerinin örgütsel bağlllı̆̆ın devamlılık boyutu üzerinde olumlu pozitif bir etkisi vardır.

H6. Çalışanların işlemsel psikolojik sözleşmelerinin örgütsel bağlılı̆̆ın normatif boyutu üzerinde olumlu pozitif bir etkisi vardır.

\section{ARAŞTIRMANIN YÖNTEMI}

$\mathrm{Bu}$ araştırma için geliştirilen modeli test etmek için sayısal verilere odaklanan nicel araştırma yöntemi kullanılmış ve verilerin toplanmasında anket tekniğinden faydalanılmıştır.

\subsection{Araştırmanın Amacı ve Modeli}

$\mathrm{Bu}$ araştırmada psikolojik sözleşme algısının örgüte bağlılık davranışı üzerinde oynadığı rolü tespit etmektir. Bu amaçla tasarlanan araştırma modeli Şekil 1'de gösterilmiştir.

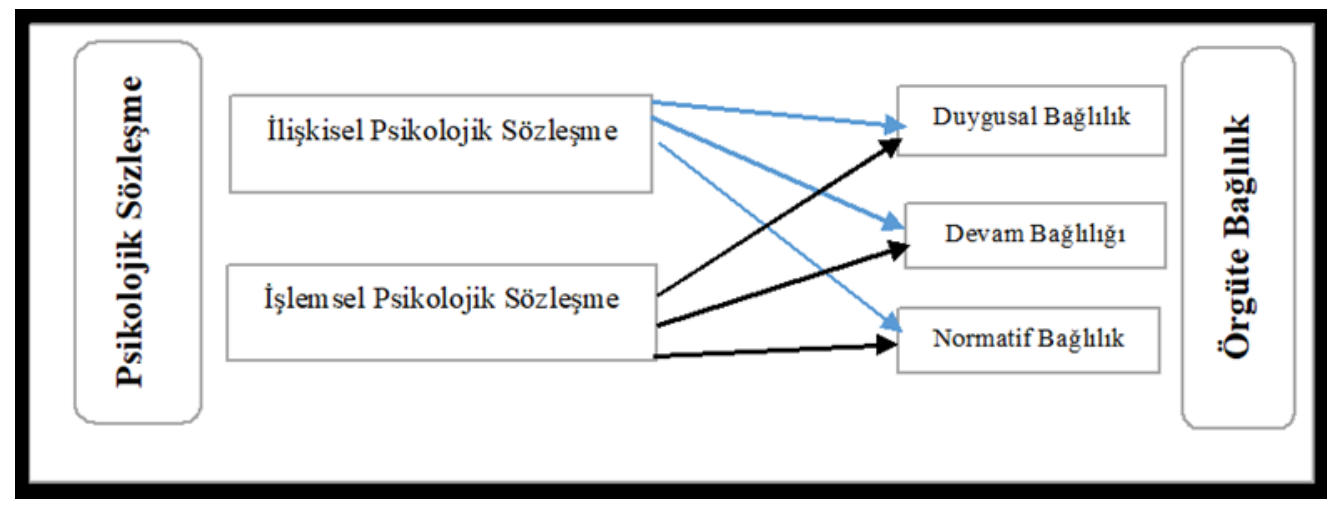

Şekil 1. Araştırma modeli

\subsection{Araştırmanın Evreni ve Örneklemi}

Araştırmanın evrenini Isparta İlinde açılmış 6 ilkokul, 8 ortaokul ve 10 Anadolu Lisesinde görev yapan 212 öğretmen oluşturmaktadır. 
İlgili okullarda görev yapan öğretmenlerin tümüne dijital ortamda gönderilen anket formlarından 142'si geri dönmüştür. Elde edilen anket formlarından hatalı ve eksik doldurduğu tespit edilen 5 adet form ve uç değer olarak belirlenen 3 adet anket formu çıkarılmış, 134 anket değerlendirmeye alınmıştır. Örneklem grubunun evreni karşılama oranı, \% 63.20’dir.

Araştırmamıza kaynaklık eden verilerin temin edilmesinde gönüllü olur/onam formu imzalatılmıştır. Araştırma verileri Süleyman Demirel Üniversitesi Üniversite Etik Kurulunun 17.07.2020 Tarih ve 94/6 Sayılı kararı ile onaylanmıştır.

\subsection{Veri Toplama Tekniği ve Kullanılan Ölçekler}

Çalışmada araştırma yapısına uygun olarak niceliksel içerik yaklaşımına dayanan Millward ve Hopkins (1998) tarafından geliştirilmiş psikolojik sözleşme ölçeği kullanılmıştır. Ölçek, 10 madde psikolojik sözleşmenin işlemsel alt boyutunu ve 7 maddesi psikolojik sözleşmenin ilişkisel alt boyutunu ölçen toplam 17 maddeden oluşmaktadır. Ölçekte ters puanlanan madde bulunmamaktadır.

Araştırmada kullanılan bir diğer ölçek, Allen ve Meyer (1990) tarafından geliştirilen; Meyer vd. (1993) tarafından yeniden gözden geçirilen ve son olarak Kurşunoğlu vd. (2010) tarafindan Türkçeye uyarlanan “18 sorulu, üç boyutlu örgütsel bağl1lık ölçeği”dir. Örgütsel bağlılık; duygusal bağlılık, devam bağlılığı ve normatif bağlılık olmak üzere üç farklı boyutta ele alınarak belirlenmeye çalışılmıştır. Her boyutu 6 maddeden oluşan ölçekte 3., 4., 5. ve 13. maddeler tersten kodlanmıştır.

\subsection{Araştırmada Kullanılan İstatistiksel Yöntemler}

Araştırma verilerinin analizinde SPSS 22 programı kullanılmıştır. Çalışmada ayrıca kullanılan ölçeklerin geçerliliğini test etmek için AMOS 20 programından yararlanılmıştır. Bu kapsamda ölçeklerin geçerliliği doğrulayıcı faktör analizi (DFA) yardımıyla geçerlenmiştir. Ölçeklerin güvenilirliğini ölçmek için ise iç tutarlılık katsayısına bakılmıştır. Değişkenlerin aralarındaki ilişkilerin ve etkilerin test edilmesinde korelasyon ve regresyon analizlerinden faydalanılmıştır.

\section{BULGULAR}

Araştırma kapsamındaki bulgular değerlendirilmiştir. 


\subsection{Katılımcılara Ait Demografik Nitelikleri}

Tablo 1. Kat1lımc1lara yönelik demografik veriler

\begin{tabular}{|c|c|c|c|}
\hline & & Sayı & Yüzde \\
\hline \multirow[t]{2}{*}{ Cinsiyet } & Erkek & 55 & 59.0 \\
\hline & Kadın & 79 & 41.0 \\
\hline \multirow[t]{3}{*}{ Eğitim } & Lisans & 100 & 73.1 \\
\hline & Yüksek Lisans & 32 & 23.9 \\
\hline & Doktora & 2 & 1.5 \\
\hline \multirow[t]{5}{*}{ Kıdem Yılı } & $1-5$ Yil & 42 & 31.3 \\
\hline & 6-10 Y1l & 28 & 20.9 \\
\hline & 11-15 Y11 & 30 & 22.4 \\
\hline & 16-20 Yil & 17 & 12.7 \\
\hline & $20+$ & 17 & 12.7 \\
\hline \multirow[t]{3}{*}{ Medeni Durum } & Evli & 82 & 61.2 \\
\hline & Bekâr & 46 & 34.3 \\
\hline & Boşanmış & 6 & 4.5 \\
\hline Toplam & & 134 & 100 \\
\hline
\end{tabular}

Araştırmaya katılan öğretmenlerin cinsiyete dayalı olarak dağılımları ağırlıklı olarak bayan öğretmenlerden oluşmaktadır. Milli Eğitim İstatistiklerine göre örgün eğitim 2019-2020 eğitim-öğretim döneminde resmi ve özel okullarda toplam 1 milyon 117 bin 686 öğretmen istihdam edilmektedir. Öğretmenlerin 174 bin 750'si ise özel okullarda görev yapryorken, toplam öğretmen mevcudunun \% 56.89'u kadınlardan oluşmaktadır. Araştırmamıza katılan kadın öğretmenlerin oranı Milli Eğitim Bakanlığının açıkladığı istatistiki oranlara yakındır. Katılımcıların \% 73.1'i Lisans seviyesinde eğitime almıştır ve araştırma grubunun yaklaşık 52.2'si 1-10 yıl arası kıdem yılına sahiptir. Kıdem yılı ile ilgili bu durum, özel okullarda iş gücü devir hızının yüksek olduğunu göstermektedir. Öte yandan katılımcıların 1/3'ünün bekâr olması, öğretmenlerin genç bir yaş grubunda yer aldığını göstermektedir.

\section{2. Ölçeklerin Geçerlilik ve Güvenilirlik Analizleri}

Bilimsel araştırmalarda kullanılan ölçeklerin ve ölçekler vasıtasıyla elde edilen verilerin normal dağılım göstermesi, bağımlı bağımsız değişkenlerin doğrusal ilişki içinde olması, hata varsayımlarının homojen dağılım göstermesi gerekmektedir (Tabachnick ve Fidel, 2014: 112). Araştırmamızda elde verilerin çarpıklık ve basıklık değerlerinin $+3,-3$ arasında olduğu tespit edilmiştir. Çarpıklık ve basıklık değerlerinin +3, -3 aralığında olması, dağılımın normalden aşarı sapma göstermediği anlamına gelmektedir (Kline, 2011: 62). Dolayısıyla elde edilen veriler normal dağılım göstermektedir. 
Ölçeklerin yapı geçerliği doğrulayıcı faktör analizi ile de sınanmıştır. Doğrulayıcı faktör analizi (DFA), daha önce belirlenmiş ya da keşfedilmiş bir ölçme aracında yer alan faktörlerin araştırmanın gerçekleştirildiği örneklemde de benzer sonuçlar verip vermediğini sınamak amacıyla yapılmaktadır (Meydan ve Şeşen, 2015: 21). Bu çalışmada Psikolojik Sözleşme Ölçeği ve Örgütsel Güven Ölçeğinin doğrulayıcı faktör analizi AMOS 22.0 programı yoluyla yapılmıştır.

Gerçekleştirilen analiz sonucunda elde edilen değerler, kabul edilebilir uyum değerler arasında olmadığından programın önerdiği modifikasyonlar yapılmıştır. Önerilen modifikasyon neticesinde modele ait değerlerin kabul edilebilir sınırlar içerisinde oluştuğu görülmüştür (Tablo 2).

Tablo 2. Ölçeklerin uyum değerleri

\begin{tabular}{|c|c|c|c|c|c|c|}
\hline & $\mathbf{X}^{2}$ & df & $\mathrm{X}^{2} / \mathrm{df}$ & GFI & CFI & RMSEA \\
\hline Psikolojik Sözleşme & 101.641 & 37 & 2.74 & 0,91 & 0.95 & 0.06 \\
\hline Örgüte Bağlılık & 211.510 & 73 & 2.89 & 0.93 & 0.98 & 0.07 \\
\hline İyi Uyum Değerleri* & & & $\leq 3$ & $\geq 0.90$ & $\geq 0.97$ & $\leq 0.05$ \\
\hline $\begin{array}{l}\text { Kabul Edilebilir Uyum } \\
\text { Değerleri }\end{array}$ & & & $\leq 4-5$ & $\geq 0.89-0.85$ & $\geq 0.95$ & $\leq 0.06-0.08$ \\
\hline & \multicolumn{6}{|c|}{$\begin{array}{l}\text { * (Meydan ve Şeşen, 2015:37, *Joreskog ve Sörbom, 1993; Kline, } \\
\text { 1998; Anderson ve Gerbing, 1984) }\end{array}$} \\
\hline
\end{tabular}

Ölçeklerin doğrulayıcı faktör analizi sonucunda elde edilen Psikolojik Sözleşme Ölçeği $(\mathrm{X} 2 / \mathrm{df}=2.74 ; \mathrm{RMSEA}=0.06 ; \mathrm{CFI}=0.95 ; \mathrm{GFI}=0.91)$ ve Örgüte Bağl1lı $(\mathrm{X} 2 / \mathrm{df}=2.89$; $\mathrm{RMSEA}=0.07$; CFI= 0.98; GFI=0.93), ölçeklerine ait uyum iyiliği değerleri ile iyi uyum değerleri arasında yer aldığından tüm ölçeklerin yapı geçerliliği sağlanmıştır. Her iki ölçeğinde orijinal çalışmalarda olduğu gibi çok faktörlü yapıları doğrulanmıştır.

Diğer taraftan ölçeklerin güvenilirliklerini ölçmek amacıyla iç tutarlılık katsayılarına bakılmıştır. Psikolojik sözleşme ölçeğinde 17 madde ve 2 boyut yer almaktadır. Ölçeğin Cronbach Alfa katsayısı 0.71'dir. Ölçeğin alt boyutlarına ilişkin Cronbach Alfa katsayıları işlemsel psikolojik sözleşme 0.69 , ilişkisel psikolojik sözleşme 0.75 olarak tespit edilmiştir.

Örgüte bağlılık ölçeğinde 18 madde ve 3 boyut yer almaktadır. Ölçeğin Cronbach Alfa katsayısı 0.81 'dir. Ölçeğin alt boyutlarına ilişkin Cronbach Alfa katsayısı duygusal bağlılık 
0.78 , devam bağl1lı̆g 0.88 ve normatif bağlılık 0.66 olarak bulunmuştur. Elde edilen iç tutarlılık katsayısına göre, kullanılan ölçeklerin güvenilir düzeyde oldukları değerlendirilmiştir (Nunnally, 1978; Sipahi vd., 2008: 89).

\subsection{Değişkenler Arası İlişkilere İlişkin Bulgular}

Psikolojik sözleşme algısı ve örgüte bağlılık ölçeğine dair ilişkiler Pearson Korelasyon analizi yardımıyla analiz edilmiştir. Bu kapsamda hazırlanan Tablo 3 'te ayrıca değişkenlere ait aritmetik ortalama, standart sapma ve varyans değerleri de verilmiştir.

Tablo 3. Ölçek maddelerine ait tanımlayıcı istatistikler

\begin{tabular}{|r|l|l|l|}
\hline & Ort. & S.s. & Varyans \\
\hline Psikolojik Sözleşme Algısı & 2.98 & .572 & .379 \\
\hline İlişkisel Sözleşme & 2.99 & .562 & .316 \\
\hline İşlemsel Sözleşme & 2.95 &, 744 & .554 \\
\hline Örgüte Bağlııkk & 3.01 & .615 & .328 \\
\hline Duygusal Bağlılık & 3.01 & .799 & .639 \\
\hline Devam Bağlı̆ı̆̆ı & 3.05 & .745 & .555 \\
\hline Normatif Bağlılık & 2.98 & .717 & .515 \\
\hline & & & \\
\hline
\end{tabular}

Örgüte bağl1lık ölçeğinin duygusal ve devam bağlılığı ölçeği boyutlarının ortalaması 3'ün üzerindedir. Normatif bağglılık ise 3'ü altındadır. Araştırmanın bir diğer ölçeği psikolojik sözleşme ölçeğinin ortalaması 3 'ün altında gerçekleşmiştir.

Tablo 4. Değişkenlere ait korelasyon analizi

\begin{tabular}{|c|c|c|c|c|c|}
\hline & $\begin{array}{c}\text { Duygusal } \\
\text { Bağll11k }\end{array}$ & $\begin{array}{c}\text { Devam } \\
\text { Bağl1l1̆ㅣ }\end{array}$ & $\begin{array}{l}\text { Normatif } \\
\text { Bağll1lk }\end{array}$ & İşlemsel PSA & İlişkisel PSA \\
\hline Duygusal Bağlılık & 1 & & & & \\
\hline Devam Bağl1lığ1 & $.595 * *$ & 1 & & & \\
\hline Normatif Bağlılık & $.246 * *$ & $.442 * *$ & 1 & & \\
\hline İşlemsel PSA & $.544 * *$ & $.361 * *$ & .058 & 1 & \\
\hline İlişkisel PSA & $.633 * *$ & $.521 * *$ & .155 & $.613 * *$ & 1 \\
\hline
\end{tabular}

$n=\ldots \ldots,{ }^{*}{ }^{*} p<.01$ 
Tablo 4'de görüldüğü üzere en yüksek korelasyon değeri .63 ile psikolojik sözleşmenin ilişkisel psikolojik sözleşme boyutu ile örgüte bağlılığın duygusal bağlılık boyutu arasında olduğu görülmektedir. Psikolojik sözleşmenin işlemsel psikolojik sözleşme boyutu ile örgüte bağl1lığın duygusal bağlılık boyutu arasında orta düzeyde $(r=.54 \mathrm{p}<.01)$, devam bağl1lı̆̆ arasında ise düşük düzeyde $(\mathrm{r}=.36 \mathrm{p}<.01)$ pozitif ve anlamlı bir ilişki olduğu görülmektedir. Psikolojik sözleşmenin ilişkisel psikolojik sözleşme boyutu ile örgüte bağlılığın duygusal bağlılık boyutu arasında orta düzeyde $(\mathrm{r}=.63 \mathrm{p}<.01)$, devam bağlılı̆̆ boyutu arasında orta düzeyde $(\mathrm{r}=.52 \mathrm{p}<.01)$, pozitif ve anlamlı bir ilişki olduğu görülmektedir.

\subsection{Hipotez Testine İlişkin Bulgular}

Tablo 5. Psikolojik sözleşme algısının örgüte bağlılığın duygusal bağlılık boyutunu yordama düzeyi

\begin{tabular}{|lllll|}
\hline $\mathrm{R}$ & $\mathrm{R}^{2}$ & Düzeltilmiș $\mathrm{R}^{2}$ & $\mathrm{Sd}$ & Durbin-Watson \\
\hline .663 & .439 & .431 & .603 & 1.70 \\
\hline
\end{tabular}

$p<.01, \mathrm{~F}=24.680, p=.000$

Tablo 5'de ki $\mathrm{R}^{2}$ değeri incelendiğinde katılımcıların psikolojik sözleşme algısının örgüte bağlılığın duygusal bağlılık boyutunun yaklaşık olarak \%44'ünü açıkladığ1 görülmektedir. Diğer bir ifade ile örgüte bağlılığın duygusal bağlılık boyutundaki varyansın \%44'ü psikolojik sözleşme boyutunun işlemsel ve ilişskisel sözleşme boyutları tarafından açıklandığı söylenebilir. Yapılan analiz sonuçlarına göre $F=.24 .680, p=.00$ modelin istatistiksel olarak anlamlı olduğu ifade edilebilir.

Tablo 6. Psikolojik sözleşme algısının örgüte bağlığın duygusal bağlılık boyutunu açıklama düzeyi ile ilgili regresyon analizi sonuçları

\begin{tabular}{|lccccccc|}
\hline & $\mathrm{B}$ & $\mathrm{Sd}$ & $\mathrm{B}$ & $\mathrm{t}$ & $\mathrm{p}$ & Tolerans & VIF \\
\hline İşlemsel PSA & .35 & .28 & .24 & 3.01 & .00 & .64 & 1.55 \\
\hline İlişkisel PSA & .51 & .08 & .48 & 5.78 & .00 & .99 & 1.00 \\
\hline
\end{tabular}

$p<.05$

Tablo 6'ya göre, psikolojik sözleşmenin işlemsel psikolojik sözleşme ve ilişkisel psikolojik sözleşme boyutunun, örgüte bağlılı̆̆ın duygusal bağlılık boyutu arasında anlamlı ve yordayıcı değişkenler olduğu ve en önemli yordayıcının ilişkisel psikolojik sözleşme boyutunda olduğu saptanmıştır. Psikolojik sözleşmenin ilişkisel psikolojik sözleşme boyutunun örgüte 
bağlılı̆̆ın duygusal bağl1lık boyutunu pozitif yönde anlamlı olarak yordadığı ifade edilebilir $(\beta=.48 ; \mathrm{t}=5.78 ; \mathrm{p}<.05)$. Diğer yandan işlemsel psikolojik sözleşme boyutunun örgüte bağlılığın duygusal bağlılık boyutunu pozitif yönde anlamlı olarak yordamaktadır. $(\beta=.24 ; \mathrm{t}$ $=3.01 ; \mathrm{p}<.05)$.

Buradan hareketle psikolojik sözleşmenin ilişkisel psikolojik sözleşme boyutundaki bir birimlik artışın örgüte bağlılığın duygusal bağlılık boyutuna ilişkin algılarını .51 birim, işlemsel psikolojik sözleşme algılarındaki bir birimlik artışın ise duygusal bağlılık boyutunda .35 birim arttıracağı ifade edilebilir. Bu sonuçlara göre katılımcıların psikolojik sözleşmenin işlemsel ve ilişkisel psikolojik sözleşme boyutlarına yönelik algılarının artması örgüte bağlılığın duygusal bağlılık algılarını da arttıracağı ifade edilebilir.

Tablo 7. Psikolojik sözleşme algısının örgüte bağlılığın devam bağlılığı boyutunu yordama düzeyi

\begin{tabular}{|lllll|}
\hline $\mathrm{R}$ & $\mathrm{R}^{2}$ & Düzeltilmiș $\mathrm{R}^{2}$ & $\mathrm{Sd}$ & Durbin-Watson \\
\hline .523 & .274 & .263 & .639 & 1.83 \\
\hline
\end{tabular}

$p<.01, \mathrm{~F}=24.680, p=.000$

Psikolojik sözleşmenin örgüte bağlılığın devam bağlılığına yönelik $\mathrm{R}^{2}$ değeri incelendiğinde katılımcıların psikolojik sözleşmenin örgüte bağl1lı̆̆ın devam bağl1lı̆̆ boyutunun yaklaşık olarak \%27'sini açıkladığı görülmektedir. Diğer bir ifade ile örgüte bağlılığın devam bağl1lı̆̆ boyutundaki varyansın \%27'si psikolojik sözleşme boyutunun işlemsel ve ilişkisel sözleşme boyutları tarafından açıklandığı söylenebilir. Yapılan analiz sonuçlarına göre $\mathrm{F}=.24 .680, \mathrm{p}=.00$ modelin istatistiksel olarak anlamlı olduğu ifade edilebilir.

Tablo 8. Psikolojik sözleşmenin örgüte bağlığın devam bağlılığı boyutunu açıklama düzeyi ile ilgili regresyon analizi sonuçları

\begin{tabular}{|lccccccc|}
\hline & $\mathrm{B}$ & $\mathrm{Sd}$ & $\mathrm{B}$ & $\mathrm{t}$ & $\mathrm{p}$ & Tolerans & VIF \\
\hline İşlemsel PSA & .08 & .12 & .06 & .70 & .48 & .64 & 1.54 \\
\hline İlişkisel PSA & .48 & .09 & .48 & 5.09 & .00 & .51 & 1.15 \\
\hline
\end{tabular}
$p<.05$

Tablo 8'e göre, psikolojik sözleşmenin ilişkisel psikolojik sözleşme boyutunun örgüte bağlılığın devam bağlılığı boyutu arasında anlamlı ve yordayıcı değişken olduğu ifade edilebilir. Psikolojik sözleşmenin ilişkisel psikolojik sözleşme boyutunun örgüte bağlılığın devam bağlılığı boyutunu pozitif yönde anlamlı olarak yordadığ 1 ifade edilebilir $(\beta=.48 ; \mathrm{t}$ 
$=5.09 ; \mathrm{p}<.05)$. Diğer yandan işlemsel psikolojik sözleşme boyutunun örgüte bağlilı̆̆ın duygusal bağlılık boyutunu pozitif yönde anlamlı olarak yordamaktadır. $(\beta=.06 ; \mathrm{t}=.70 ; \mathrm{p}<.05)$.

Tablo 9. Psikolojik sözleşme algısının örgüte bağlılığın normatif bağlılık boyutunu yordama düzeyi

\begin{tabular}{|lllll|}
\hline $\mathrm{R}$ & $\mathrm{R}^{2}$ & Düzeltilmiş $\mathrm{R}^{2}$ & $\mathrm{Sd}$ & Durbin-Watson \\
\hline .162 & .026 & .011 & .713 & 1.75 \\
\hline
\end{tabular}

$p<.01, \mathrm{~F}=66.236, p=.000$

Psikolojik sözleşme algısının örgüte bağl1lı̆̆ın normatif bağlılık düzeyine yönelik $\mathrm{R}^{2}$ değeri katılımcıların psikolojik sözleşme algısının örgüte bağlılığın normatif bağlılık boyutunun yaklaşık olarak \% 02'sini açıkladığı görülmektedir. Diğer bir ifade ile örgüte bağlılığın normatif bağlılığı boyutundaki varyansın \% 02 'si gibi oldukça düşük oranla psikolojik sözleşme boyutunun işlemsel ve ilişkisel sözleşme boyutları tarafından açıklandığı söylenebilir. Yapılan analiz sonuçlarına göre $\mathrm{F}=.66 .236, \mathrm{p}=.00$ modelin istatistiksel olarak anlamlı olduğu ifade edilebilir.

Tablo 10. Psikolojik sözleşmenin örgüte bağlı̆̆ın normatif bağlılık boyutunu açıklama düzeyi ile ilgili regresyon analizi sonuçları

\begin{tabular}{|c|c|c|c|c|c|c|c|}
\hline & $\mathrm{B}$ & $\mathrm{Sd}$ & $\mathrm{B}$ & $\mathrm{t}$ & $\mathrm{p}$ & Tolerans & VIF \\
\hline İşlemsel PSA & -.07 & .13 & -.06 & -.54 & .58 & & \\
\hline İlişkisel PSA & .18 & .10 & .19 & 1.7 & .08 & & \\
\hline
\end{tabular}

$p<.05$

Psikolojik sözleşmenin işlemsel ve ilişkisel boyutlarının örgüte bağlılığın normatif bağlılık üzerinde anlamlı ve yordayıcı değişken olmadığı tespit edilmiştir.

\section{SONUÇ VE TARTIŞMA}

Bu çalışmanın amacı, özel okullarda görev yapan öğretmenlerin, psikolojik sözleşme algılarının örgüte bağlılık davranışını ne düzeyde etkilediğini belirlemektir.

Psikolojik sözleşmenin alt boyutu olan ilişkisel sözleşmenin, örgüte bağlılığın duygusal bağlılık ve devam bağlılığı arasında pozitif ve anlamlı ilişski vardır. Psikolojik sözleşme işlemsel psikolojik sözleşme boyutu ile örgüte bağl1lığın duygusal bağlllık boyutu arasında orta düzeyde, devam bağlılığı boyutu arasında düşük düzeyde pozitif ve anlamlı ilişki tespit edilmiştir. Psikolojik sözleşmenin her iki boyutunun, örgüte bağlılı̆̆ın normatif bağlılık boyutu 
arasında herhangi bir ilişki tespit edilmemiştir. Bu bağlamda katılımcıların ilişkisel ve işlemsel psikolojik sözleşme algısı arttıkça duygusal ve devam bağlılığına ilişkin algıları da artmaktadır.

Katılımcıların psikolojik sözleşmenin işlemsel ve ilişkisel psikolojik sözleşme boyutlarına ilişkin algıları, örgüte bağlılığın duygusal bağlılık boyutunun yaklaşık olarak \%44'ünü, devam bağlılığının \%27'sini, normatif bağl1lığının ise \%02'sini açıkladığı görülmektedir.

Psikolojik sözleşmenin işlemsel ve ilişkisel sözleşme boyutlarının örgüte bağlılığın duygusal ve devam bağlılık üzerinde olumlu ve anlamlı yordayıcı olduğu, psikolojik sözleşmeye yönelik algıları arttıkça örgüte bağlılıkları artacağı ifade edilebilir. Psikolojik sözleşmenin örgüte bağlılık üzerinde pozitif ve anlamlı bir etkisi vardır.

Oldukça zor ve özveri gerektiren bir meslek olarak ifade edilen öğretmenliğin en önemli istihdam alanı kamu sektörüdür. 2019 MEB istatistiklerine göre özel okullarda çalışan öğretmen sayısı tüm okul türlerinde 148.676'dır. Özel okullarda görev yapan öğretmenler, kamuda görev yapan öğretmenlerin yaklaşık \%16'sıdır. Dolayısıyla hiç de azımsanmayacak bir öğretmen grubu özel okullarda istihdam edilmektedir. Diğer yandan özel okulların kamuya ait okullar ve diğer özel okullarla ciddi bir şekilde rekabet etmek zorunda kalmaları, istihdam ettikleri öğretmenlerin gösterecekleri gayret ve performansı daha önemli hale getirmektedir. Dolayısıyla özel okul görev yapan öğretmenlerin psikolojik sözleşme algıları ve çalıştıkları okullara bağlılıkları üzerinde dikkatli bir şekilde durulması gereken bir konu haline gelmektedir.

Alanyazında psikolojik sözleşme ve örgüte bağlılık değişkeni üzerine çeşitli çalışmalar gerçekleştirilmiştir. Araştırmamızda elde edilen sonuçlar, Karcıoğlu ve Türker (2010) ve Ceseroğlu (2010), Keman (2012), Mahia ve Bastos (2015), Tsui vd. (2013), Çetin (2010) ve Özgen ve Özgen (2010), Demiral'ın (2008) elde ettiği bulgular ile örtüşmektedir. Öte yandan araştırma sonuçlarımızın, psikolojik sözleşmenin yokluğunu ifade eden psikolojik sözleşme ihlalinin örgütsel bağlılığın azalmasına neden olduğunu ileri süren çalışmalarla (Robinson vd., 1994; Robinson ve Rousseau, 1994; Robinson ve Morrison, 1995; Robinson, 1996; Turnley ve Feldman, 1999) uyumlu olduğu görülmüştür.

Araştırma neticesinde, psikolojik sözleşme algısının örgütlerde bağlılık davranışına olumlu düzeyde etkisinin ortaya konulmasının alanyazına bir katkı sağladığı değerlendirilmektedir. 
Araştırmada elde edilen psikolojik sözleşmenin örgüte bağlılık davranışına olumlu düzeyde kaynaklık edeceğine dair güçlü verilerin, uygulayıcılar tarafından örgütsel düzeyde dikkatle izlenmesi gerektiğini ifade edilebilir. Araştırma sonuçları özellikle özel okul yöneticilerine, insan kaynakları yöneticilerine psikolojik sözleşme ve örgüte bağlılık açısından önemli mesajlar barındırmaktadır. Örgütler çalışanların örgüte bağlılıklarının yüksek olmasına yönelik, çalışanların psikolojik sözleşmesini anlamak/tanımak ve ona uygun hareket etmek durumundadır. Diğer bir ifade ile örgütler yüksek düzeyde psikolojik sözleşme uyum algısına sahip çalışanları istihdam etmek ve çalışanların örgüte bağlılıklarını artırıcı politikalar geliştirmelidir. Çünkü örgüte bağlılığı sağlanmış çalışanların ekstra rol davranışları sergileyerek örgütün rekabet edilebilirliğini arttırmaktadır. Dolayısıyla bir özveri mesleğini icra eden öğretmenlerin psikolojik sözleşmeleri dikkate alınmalıdır.

Araştırmada bazı kısıtlar da söz konusudur. Bunlardan ilki, bu çalışmanın sadece sınırlı sayıda özel okulun bulunduğu bir ilde ve pandemiye bağlı olarak eğitim ile ilgili uzaktan/fiziki eğitim gibi tartışmaların gündemde olduğu bir dönemde yapılmış olmasıdır. Bir diğer kısıt ise, araştırma sonuçlarının genelleştirilebilmesi için farklı illerde ve farklı örneklemler üzerinde araştırmanın tekrarlanmasında fayda görülmektedir.

\section{REFERENCES / KAYNAKLAR}

Cassar, V. (2001). Violating psychological contract terms amongst maltese public service employees: Occurrence and relationships. Journal of Managerial Psychology, 16(3), 194-208.

Çetinkaya, F. F. (2014). Hizmet işletmelerinde psikolojik sözleşme ihlalleri ve örgütsel sinizm iliş̧kisi; Kapadokya bölgesi 4 ve 5 ylldızlı otel işletmelerinde bir araştırma (Yayınlanmamış doktora lisans tezi). Afyon Kocatepe Üniversitesi, Afyon.

Demiral, Özge (2008). Örgütsel bağlllı̆ğn sağlanmasında personel güçlendirme ve psikolojik sözleşmenin etkisine ilişkin bir araştırma (Yayınlanmamış yüksek lisans tezi). Niğde Ömer Halisdemir Üniversitesi, Niğde.

Dikili, A. \& Bayraktaroğlu, S. (2013). Psikolojik sözleşme ile iş tatmini ilişkisine yönelik bir araştırma. Eskişehir Osmangazi Üniversitesi IIBFF Dergisi, 8(2), 205-227.

Erdil, O. \& Keskin, H. (2003). Güçlendirmeyle iş tatmini, iş stresi ve örgütsel bağglılık arasındaki ilişkiler: Bir alan çalışması. İ.Ü. İsletme Fakültesi Dergisi, 32(1),7-24.

Gefen, D. \& Ridings, C. M. (2002). Implementation team responsiveness and user evaluation of customer relationship management: A quasi-experimental design study of social exchange theory. Journal of Management Information Systems, 19(1), 47-69.

Gouldner, A.W. (1960). The norm of reciprocity. American Sociological Review, 25, 161.

J. P. Meyer \& N. J. Allen, A. (1991). Three-component conceptualization of organizational commitment. Human Resource Management Review, 1(1), 61-89. 
Karcıŏglu, F. \& Türker, E. (2010). Psikolojik sözleşme ile örgütsel bağlılık ilişkisi: Sağlık çalışanları üzerine bir uygulama. Atatürk Üniversitesi İktisadi ve İdari Bilimler Dergisi, 24(2), 121-140.

Kidder, D. L. \& Buchholtz, A. K. (2002). Can excess bring success? CEO compensation and the psychological contract. Human Resource Management Review, 12(4), 599-617.

Kotter, J. (1973). The psychological contract: Managing the joining-up process. California Management Review, 15(9), 91-99.

Lemire, L. \& Christian R. (2005). An empirical exploration of psychological contract violation and individual behaviour: The case of Canadian federal civil servants in quebec. Journal of Managerial Psychology, 20(2), 150163.

Meydan, H.C. \& Şeşen, H. (2015). Yapısal eşitlik modellemesi AMOS uygulamaları. İstanbul: Detay Yayıncılık.

McCormick, E. J. \& Ilgen, D.R. (1980). Industrial psychology. New Jersey: Prentice Hall.

Mimaroğlu, H. (2008). Psikolojik sözleşmenin personelin tutum ve davranışlarına etkileri: Tıbbi satış temsilcileri üzerinde bir araştırma (Basılmamış Doktora Tezi). Çukurova Üniversitesi, Adana.

Millward, L. J. \& Brewerton, P. (2000). International review of industrial and organizational psychology, psychological contracts: Employee relations for the 21st century. (C. Cooper \& I. Robertson, Derl.) Chichester: John Wiley \& Sons, Inc.

Mowday, R. T. \& Steers, R. M. (1979). The measurement of organization commitment. Journal of Vacational Behavior.

N. J. Allen, J. P. Meyer \& John P. (1990). The measurement and antecedents of affective, continuance and normative commitment to the organization. Journal of Occupational Psychology, 63, 1-18.

Özgen, M. H. (2010). Psikolojik sözleşme ve boyutlarının güven üzerindeki etkileri: Sivas ili kamu personeli üzerine bir araştırma. 18. Ulusal Yönetim ve Organizasyon Kongresi.

Rousseau, D. M. (1990). New hire perceptions of their own and their employer's obligations: A study of psychological contracts. Journal of Organizational Behaviour, 11, 389-400.

Selekler, O. Z. (2007). Öğretmenlerde örgütsel adalet ve psikolojik sözleşme ihlâl algısı (Basılmamış yüksek lisans tezi). Kocaeli Üniversitesi, Kocaeli.

Schein, E. H. (1980). Organisational psychology. Englewood Cliffs, NJ: PrenticeHall.

Saylı, H. (2002). Örgütsel değişimde psikolojik sözleşme ihlâlleri ve bir uygulama örneği (Basılmamış doktora tezi). Afyon Kocatepe Üniversitesi, Afyon.

Vroom, V. H. (1964). Work and motivation. New York: John Wiley \& Sons.

Ward, S. G., Brooke, R., Langford, E. \& M. (2007). On the theory of psychological contracts in family firms. The Entrepreneurial Executive, 12, 37-50.

Willems, I., Janvier, R. \& Henderickx, E. (2006). New pay in European civil services: Is the psychological contract changing? International Journal of Public Sector Management, 19(6), 609-621.

Zhoa, H. W., Sandy, J. Glibkowski, B. C. \& Bravo, J. (2007). The impact of psychological contract breach on work-related outcomes: A meta-analysis. Personel Psychology, 60(3), 647-680. 